\title{
Fish oil replacement by soybean oil in the diet of fat snook juveniles
}

\author{
Fabiano Bendhack(1), Ana Paula Baldan ${ }^{(2)}$ and Thiago El Hadi Perez Fabregat ${ }^{(3)}$
}

\begin{abstract}
(1)Universidade Federal do Paraná, Centro de Estudos do Mar, Caixa Postal 61, CEP 83255-976 Pontal do Paraná, PR, Brazil. E-mail: fabiano.b@ufpr.br (2)Pontifícia Universidade Católica do Paraná, Escola de Ciências Agrárias e Medicina Veterinária, Rodovia BR-376, Km 14, CEP 83010-500 São José dos Pinhais, PR, Brazil. E-mail: ana.baldan@pucpr.br ${ }^{(3)}$ Universidade do Estado de Santa Catarina, Centro de Ciências Agroveterinárias, Avenida Luís de Camões, no 2.090, CEP 88520-000 Lages, SC, Brazil. E-mail: thiagofabregat@hotmail.com
\end{abstract}

\begin{abstract}
The objective of this work was to evaluate fish oil replacement by soybean oil in diets, as for the effects on the performance and body composition of juveniles of fat snook (Centropomus parallelus). The experiment was carried out in a randomized block design, with three treatments (lipid sources) and six replicates, in a 60-day period. Fat snook juveniles $(24.17 \pm 0.28 \mathrm{~g})$ were distributed in 18 experimental tanks of $200 \mathrm{~L}$ each, equipped with aeration and heating systems, under continuous water renovation (800\% per day). Three isoproteic $(44 \% \mathrm{CP})$ and isoenergetic $\left(4,635 \mathrm{kcal} \mathrm{CE} \mathrm{kg}^{-1}\right)$ diets were formulated to comprise three replacement rates $(0,50$, and $100 \%)$ of fish oil by soybean oil. Biometric analyses were done to evaluate fish performance, and two entire specimens from each replicate were used for body composition analyses. The zootechnical indices of weight gain $(38.68 \pm 5.41 \mathrm{~g})$, feed conversion $(1.38 \pm 0.10)$, and specific growth at $1.70 \pm 0.18 \%$ weight gain per day were considered satisfactory. Lipid source substitution does not affect the performance and body composition of fat snook juveniles, which suggests that soybean oil can replace fish oil in diet formulation.
\end{abstract}

Index terms: Centropomus parallelus, body composition, fatty acids, marine fish, nutrition.

\section{Substituição do óleo de peixe por óleo de soja em dietas para juvenis de robalo-peva}

\begin{abstract}
Resumo - O objetivo deste trabalho foi avaliar a substituição do óleo de peixe por óleo de soja em dietas, quanto ao efeito no desempenho e na composição corporal de juvenis de robalo-peva (Centropomus parallelus). O experimento foi realizado em delineamento de blocos ao acaso, com três tratamentos (fonte de lipídeos) e seis repetições, pelo período de 60 dias. Juvenis de robalo-peva $(24,17 \pm 0,28 \mathrm{~g})$ foram distribuídos em 18 tanques experimentais de $200 \mathrm{~L}$ cada um, equipados com sistemas de aeração e aquecimento, com renovação contínua da água ( $800 \%$ ao dia). Três dietas isoproteicas $(44 \% \mathrm{~PB})$ e isoenergéticas $\left(4.635 \mathrm{kcal} \mathrm{EB} \mathrm{kg}^{-1}\right)$ foram formuladas para abranger três níveis de substituição $(0,50$ e 100\%) do óleo de peixe pelo óleo de soja. Realizaram-se avaliações biométricas quanto ao desempenho, e dois animais por repetição foram utilizados para análises de composição corporal. Os índices zootécnicos de ganho de peso $(38,68 \pm 5,41 \mathrm{~g})$, conversão alimentar $(1,38 \pm 0,10)$ e taxa de crescimento específico a $1,70 \pm 0,18 \%$ do peso vivo por dia foram considerados satisfatórios. A substituição da fonte de lipídeo não afeta o desempenho nem a composição corporal de juvenis de robalo-peva, o que é uma indicação de que o óleo de soja pode substituir o óleo de peixe na formulação de dietas.
\end{abstract}

Termos para indexação: Centropomus parallelus, composição corporal, ácidos graxos, peixe marinho, nutrição.

\section{Introduction}

Fat snook, Centropomus parallelus, is a marine species with great potential for aquaculture. This species meat is highly priced; filleting is easily accomplished and reaches a high, bone-free fillet yield (Souza et al., 2011). Fat snook attains one of the top market values, in comparison to both freshwater and marine fish in Brazil. However, restricted fishery supplies limit their production. Recent studies have focused on the biology and the development of culture techniques for this species (Cerqueira, 2005). Because of its osmoregulation capacity, fat snook inhabits coastal areas, including estuaries and rivers, and is easily adapted to both freshwater and brackish water. More specifically, this species exhibits euryhaline 
habits throughout its life cycle, by inhabiting freshwater environments as adults and migrating to saltwater environments to reproduce (Cerqueira, 2005).

Supplementation of n-3 long-chain polyunsaturated fatty acids, such as eicosapentaenoic (EPA) and docosahexaenoic acid (DHA), is essential in the diets for marine fish, whereas freshwater species might feed on both n-3 and n-6 fatty acids (El-Sayed et al., 2005). As fat snook is typically estuarine, occurring also in freshwater ecosystems, the supplementation of high levels of n-3 long-chain polyunsaturated fatty acids might be nonessential to their growth.

The incorporation of n-3 long-chain polyunsaturated fatty acids during the rearing of fat snook larvae affected neither growth nor survival of 14-day post-hatched larvae (Seiffert et al., 2001), but it improved the survival rates and stress tolerance of larvae at 21 days post-hatch (Moschem, 2000). Yanes-Roca et al. (2009) found differences in the quality of embryos and in the survival rate of larvae, among the different seasons, which are correlated to fatty acids deposition in $C$. undecimalis females. Although researching on the supplementation with polyunsaturated fatty acids have been reported for larval and embryonic phases, the requirement of essential fatty acids for fat snook juveniles should be still defined.

Polyunsaturated fatty acids supplementation has been shown as unnecessary in the developmental phase for other species, and the substitution of fish oil by vegetable oil does not affect fish performance and growth (Hunt \& Tekelioglu, 2008; Ding et al., 2009; Borges et al., 2014).

The objective of this work was to evaluate fish oil replacement by soybean oil in diets, as for the effects on the performance and body composition of juveniles of fat snook (Centropomus parallelus).

\section{Materials and Methods}

The experiment was performed in a 60-day period, at the Centro de Produção de Organismos Marinhos (CPPOM), located in Guaratuba, Brazil. Two hundred sixteen juveniles of fat snook, with $24.17 \pm 0.28 \mathrm{~g}$ mean weight, were separated into 18 experimental glass tanks of $200 \mathrm{~L}$ each, equipped with aeration and heating systems, and with continuous water renovation $(800 \%$ per day). A randomized experimental block design was carried out with three treatments (lipid sources) and six replicates. Fish tanks were placed on shelves and each shelf was considered as a block.

Three isoproteic $44 \%$ crude protein (CP) and isoenergetic 4,635 kcal kg-1 crude energy (CE) diets, comprising three substitution rates $(0,50$ and $100 \%)$ of fish oil by soybean oil, were formulated (Table 1). Fatty acid compositions in each diet are shown in Table 2. To prepare the diets, all ingredients were ground in a hammer mill, then they were manually mixed, moisturized and pelletized. Pellets were dried in a ventilated chamber, at $55^{\circ} \mathrm{C}$ for 24 hours, and stored at $-20^{\circ} \mathrm{C}$ until time of application. Bromatological analyses of the diets were accomplished according to Horwitz (1997), and the analysis of the fatty acid profile was performed by liquid chromatography.

Fish were fed twice a day up to apparent satiation to reduce the presence of feed leftovers. Organic matter deposited in the bottom of the tanks was removed daily by siphoning, and water was partially renewed. Mean

Table 1. Ingredients and proximal composition of experimental diets for fat snook juveniles.

\begin{tabular}{lccc}
\hline $\begin{array}{l}\text { Ingredient } \\
(\%)\end{array}$ & $\begin{array}{c}\text { Fish } \\
\text { oil }\end{array}$ & $\begin{array}{c}\text { Fish oil }+ \\
\text { soybean oil }\end{array}$ & $\begin{array}{c}\text { Soybean } \\
\text { oil }\end{array}$ \\
\hline Fish meal & 52.0 & 52.0 & 52.0 \\
Soybean meal & 22.5 & 22.5 & 22.5 \\
Corn starch & 8.36 & 8.36 & 8.36 \\
Wheat meal & 6.6 & 6.6 & 6.6 \\
Soybean oil & - & 5.0 & 10.0 \\
Fish oil & 10.0 & 5.0 & - \\
Vitamin and mineral mix ${ }^{(1)}$ & 0.5 & 0.5 & 0.5 \\
C vitamin & 0.04 & 0.04 & 0.04 \\
\hline Total & 100.0 & 100.0 & 100.0 \\
\hline Proximate composition & & & \\
$\quad$ Dry matter & 92.24 & 92.24 & 92.24 \\
Crude protein & 43.94 & 43.94 & 43.94 \\
Fat & 15.74 & 15.74 & 15.74 \\
Nitrogen-free extract & 17.30 & 17.30 & 17.30 \\
Crude fiber & 2.73 & 2.73 & 2.73 \\
Calcium & 3.36 & 3.36 & 3.36 \\
Phosphorus & 2.04 & 2.04 & 2.04 \\
Energy (kcal kg-1) & $4,635.28$ & $4,635.28$ & $4,635.28$ \\
\hline
\end{tabular}

${ }^{(1)} \mathrm{Mix}$ contents (per kg of mix) are the following vitamins and minerals: A, 2,500,000 UI; D3, 500,000 UI; E, 20,000 UI; K, 3,500 mg; C, 25,000 mg; B12, 10,000 mg; B1, 7,000 mg; B2, 7,425 mg; B6, 7,250 mg; biotin $50 \mathrm{mg}$; folic acid 1,500 mg; pantothenic acid 20,000 mg; choline, $165 \mathrm{mg}$; $\mathrm{Fe}$, 25,000 mg; Cu, 3,000 mg; Mn, 15,000 mg; I, $660 \mathrm{mg}$; Se, $110 \mathrm{mg}$; and Zn, $30,000 \mathrm{mg}$. 
temperature $\left({ }^{\circ} \mathrm{C}\right)$ of water in the experimental tanks was measured daily with an alcohol thermometer; in addition, water salinity (\%o), with a Biobrix refractometer, model 211 (Equipar - Equipamentos Laboratoriais e Hospitalares, Curitiba, PR, Brazil); total ammonia concentration in $\mathrm{mg} \mathrm{L}^{-1}$, according to Eaton et al. (2005); and pH, using a pHmeter, model YSI pH100 (YSI Inc., Yellow Springs, OH, USA), were determined weekly. Physicochemical water qualities showed no significant differences among treatments.

Table 2. Fatty acids composition in experimental diets (\%o) for fat snook juveniles.

\begin{tabular}{lccc}
\hline Fatty acid & $\begin{array}{c}\text { Fish } \\
\text { oil }\end{array}$ & $\begin{array}{c}\text { Fish oil }+ \\
\text { soybean oil }\end{array}$ & $\begin{array}{c}\text { Soybean } \\
\text { oil }\end{array}$ \\
\hline C12:0 & 0.100 & 0.093 & 0.068 \\
C13:0 & 0.031 & 0.032 & 0.035 \\
C14:0 ISSO & 0.029 & 0.026 & 0.024 \\
C14:0 & 3.383 & 2.686 & 1.953 \\
C15:0 ANTEISO & 0.351 & 0.302 & 0.274 \\
C14:1 C9 & 0.120 & 0.091 & 0.092 \\
C15:0 & 0.462 & 0.461 & 0.409 \\
C16:0 ISSO & 0.196 & 0.229 & 0.262 \\
C16:0 & 21.442 & 21.484 & 21.164 \\
C17:0 ISSO & 0.500 & 0.512 & 0.472 \\
C16:1 C9 & 7.316 & 6.286 & 5.691 \\
C17:0 & 1.021 & 1.043 & 0.978 \\
C17:1 & 1.071 & 0.486 & 0.386 \\
C18:0 & 6.246 & 6.551 & 6.453 \\
C18:1 C9 & 22.770 & 24.194 & 22.782 \\
C18:1 C11 & 0.883 & 0.470 & 1.019 \\
C18:1 C12 & 0.534 & 0.207 & 0.590 \\
C18:1 C13 & 1.69 & 0.96 & 0.59 \\
C18:1 T16 & & & \\
C18:1 C15 & 0.295 & 0.119 & 0.259 \\
C18:2 C9 C12 n-6 & 0.157 & 0.062 & 0.103 \\
C18:3 n-3 & 0.245 & 0.205 & 0.052 \\
C24:0 & 9.705 & 15.090 & 20.753 \\
C22:1 & 1.416 & 2.008 & 2.680 \\
C22:2 & 0.225 & 0.179 & 0.210 \\
C20:5 n-3 EPA & 1.616 & 1.664 & 1.484 \\
C22:5 n-3 & 0.492 & 0.370 & 0.281 \\
C22:6 n-3 DHA & 4.434 & 3.762 & 2.574 \\
Total saturated fatty acids & 2.777 & 2.052 & 1.560 \\
Total monounsatured fatty acids & 34.99 & 33.78 & 32.45 \\
Total polyunsatured fatty acids & 26.64 & 31.61 & 34.48 \\
Total n-6 fatty acids & 9.705 & 15.090 & 20.753 \\
Total n-3 fatty acids & 16.43 & 14.49 & 12.258 \\
\hline & & 6.674 & 5.444 \\
& & 33.59 & 31.32 \\
& & & \\
& & &
\end{tabular}

Mean values of temperature, salinity, total ammonium, and $\mathrm{pH}$ were $26.4 \pm 0.53^{\circ} \mathrm{C}, 27.0 \pm 3.1 \%$ o, $0.20 \pm 0.07 \mathrm{mg}$ $\mathrm{L}^{-1}$, and $7.77 \pm 0.38$, respectively. These values are within the appropriate limits for fat snook production (Cerqueira, 2005). No mortality was observed during the experimental period.

Biometry analyses were conducted at the beginning and after 60 days of the experiment. Prior to biological material collection and biometric analyses, fish were anesthetized with benzocaine at $50 \mathrm{mg} \mathrm{L}^{-1}$. Body composition was determined in two whole specimens from each replicate, and the analysis was done according to Horwitz (1997). For the performance analysis, all the 12 fish from each experimental unit were sampled.

Indices related to performance and body composition were calculated based on the data from the biometric and body composition analyses, as follows: survival $(\%)=100$ (final number of individuals/initial number of individuals); total weight gain $(\mathrm{g})=$ final weight - initial weight; specific growth rate (\% per day) $=100$ (ln final mean weight $-\ln$ initial mean weight $) /$ number of days; apparent feed conversion $=$ ingested feed/weight gain; hepatosomatic index $=100$ (liver weight/body weight); and, viscerosomatic fat index = 100 (fat weight in viscera/body weight).

Statistical analyses were performed using the software SAS, version 8.0. (SAS Institute, Cary, CA, USA). The normality test (Cramer-von Mises) showed errors in a normal distribution ( $\mathrm{p}>0.25)$ and, then, an analysis of variance was performed. Mean values were compared by Tukey's test, at $5 \%$ probability.

\section{Results and Discussion}

Soybean oil had no influence on the performance of fat snook juveniles (Table 3). Body composition and tissue indices remained unchanged among the different treatments (Table 4). Previous studies showed that diet supplementation with long-chain polyunsaturated fatty acids is unnecessary during the initial larval phases. Supplementation with rotifers for 14 days, containing just $1.81 \%$ EPA and $0.06 \%$ DHA, had no deleterious effect on both growth and survival of fat snook larvae, in comparison to larvae fed on enriched rotifers with 13.2\%o EPA and 6.1\%o DHA (Seiffert et al., 2001). Fat snook larvae fed on enriched brine shrimps with n-3 long-chain 
fatty acids, for 21 days, improved their survival and tolerance to stress; however, their growth remained unaffected (Moschem, 2000).

The lack of long-chain fatty acids in vegetal oils might have been overcome by the diet formulated with $52 \%$ marine fishmeal, which provided about $2.5 \%$ EPA and 5.4\% DHA to the diet. These values are close to the ones used in feed formulas distributed to other marine species (Peng et al., 2008; Ding et al., 2009), suggesting that, depending on the diet composition, supplementation with EPA and DHA might be unnecessary to feed juveniles of fat snook. Similar results have also been reported for Solea senegalensis (Borges et al., 2014).

Body composition parameters and tissue indices remained the same among treatments (Table 4). The substitution of fish oil by soybean oil had no effects on fish development. A similar finding was reported for Dicentrarchus labrax, in an experiment by which fish received the same amount of fishmeal, and fish oil source was replaced by soybean oil (Hunt \& Tekelioglu, 2008). Similar results were also shown for Rachycentron canadum, for which the higher amounts of diet-supplementation with EPA and DHA than those already present in fishmeal did not improve fish performance (Ding et al., 2009).

The requirements of EPA and DHA for fat snook were not determined. In the case of seabass, D. labrax, the requirements of long-chain polyunsaturated fatty acids (PUFAs) were equal to $0.7 \%$ in the dry matter of diets with $18 \%$ lipids (Ali-Skalli \& Robin, 2004). In the present study, the total percentage of main PUFAs in the dry matter of the diet without fish oil was $0.79 \%$, which is within the required threshold for fat snook.

Table 3. Performance of fat snook fed diets at different levels of soybean supplementation ${ }^{(1)}$.

\begin{tabular}{lcccc}
\hline Parameter & $\begin{array}{c}\text { Fish } \\
\text { oil }\end{array}$ & $\begin{array}{c}\text { Fish oil }+ \\
\text { soybean oil }\end{array}$ & $\begin{array}{c}\text { Soybean } \\
\text { oil }\end{array}$ & $\begin{array}{c}\text { CV } \\
(\%)\end{array}$ \\
\hline Initial weight $(\mathrm{g})$ & $24.08 \pm 0.3 \mathrm{a}$ & $24.21 \pm 0.3 \mathrm{a}$ & $24.21 \pm 0.3 \mathrm{a}$ & 1.16 \\
Final weight $(\mathrm{g})$ & $61.19 \pm 5.71 \mathrm{a}$ & $62.66 \pm 4.66 \mathrm{a}$ & $62.89 \pm 5.46 \mathrm{a}$ & 6.61 \\
Weight gain $(\mathrm{g})$ & $37.11 \pm 5.70 \mathrm{a}$ & $38.45 \pm 4.74 \mathrm{a}$ & $38.68 \pm 5.41 \mathrm{a}$ & 11.13 \\
TCR $(\mathrm{g})$ & $54.07 \pm 4.44 \mathrm{a}$ & $54.03 \pm 5.32 \mathrm{a}$ & $53.36 \pm 4.75 \mathrm{a}$ & 5.26 \\
AFC & $1.47 \pm 0.14 \mathrm{a}$ & $1.40 \pm 0.05 \mathrm{a}$ & $1.38 \pm 0.10 \mathrm{a}$ & 7.56 \\
SGR $\left(\%\right.$ day $\left.^{-1}\right)$ & $1.66 \pm 0.17 \mathrm{a}$ & $1.69 \pm 0.17 \mathrm{a}$ & $1.70 \pm 0.18 \mathrm{a}$ & 8.09 \\
\hline
\end{tabular}

${ }^{(1)}$ Means followed by equal letters, in the rows, do not differ by Tukey's test, at $5 \%$ probability. TCR, total consumed ration. AFC, apparent feed conversion. SGR, specific growth rate.
The diet in the present study, however, showed $15 \%$ of lipids.

Despite the lack of differences in the results between diets, fat snook performance in the present experiment was outstanding and reached $1.7 \%$ weight gain per day of specific growth rate. Until present, specific growth rates reported for this species, reared in different systems, were remarkably lower than those obtained in the present work, usually ranging from 0.5 to $0.9 \%$ body weight per day (Zarza-Meza et al., 2006; Ostini et al., 2007; Tsuzuki et al., 2008; Souza et al., 2011). Only one study has noted a specific growth rate above $1 \%$ for fat snook (Tsuzuki \& Berestinas, 2008). Nonetheless, the apparent feed conversion remained unchanged, in comparison to the same, previously mentioned studies on this species, despite the higher growth observed in the present study.

Total fat deposition in fish (mean 7.7\%) was higher than that reported by Souza et al. (2011), after 90 days using a diet with a similar composition (5.48\%). The available results about fat composition, however, are quite variable, constraining further conclusions about this subject. For instance, for fat snook fed a balanced diet formulated for shrimps, fat deposition increased up to $8.3 \%$ (Tsuzuki \& Berestinas, 2008). In comparison to other marine species, such as D. labrax, a mean value of $6.37 \pm 1.5 \%$ was detected in nine studies which analyzed commercial diets for this well-accepted species in the European market (Grigorakis, 2007). Fat deposition in the viscera were $4.95 \%$. There are no reports on a viscerosomatic fat index for fat snook, but by a compilation of five reports with $D$. labrax (Grigorakis, 2007), visceral fat deposition was higher $(5.7 \%)$.

Table 4. Body composition and tissue index of fat snook fed diets at different levels of soybean supplementation ${ }^{(1)}$.

\begin{tabular}{|c|c|c|c|c|}
\hline Composition & Fish oil & $\begin{array}{c}\text { Fish oil + } \\
\text { soybean oil }\end{array}$ & $\begin{array}{c}\text { Soybean } \\
\text { oil }\end{array}$ & $\begin{array}{l}\text { CV } \\
(\%)\end{array}$ \\
\hline Moisture (\%) & $73.1 \pm 1.3 \mathrm{a}$ & $72.3 \pm 0.5 \mathrm{a}$ & $73.0 \pm 1.4 \mathrm{a}$ & 2.4 \\
\hline Protein $(\%)$ & $14.8 \pm 0.3 \mathrm{a}$ & $15.0 \pm 0.1 \mathrm{a}$ & $14.6 \pm 0.2 \mathrm{a}$ & 2.0 \\
\hline Fat (\%) & $7.6 \pm 0.5 \mathrm{a}$ & $7.9 \pm 0.2 \mathrm{a}$ & $7.6 \pm 0.3 \mathrm{a}$ & 5.1 \\
\hline Ash (\%) & $4.4 \pm 0.3 \mathrm{a}$ & $4.5 \pm 0.4 \mathrm{a}$ & $4.6 \pm 0.2 \mathrm{a}$ & 6.7 \\
\hline \multicolumn{5}{|l|}{ Tissues index } \\
\hline Hepatosomatic (\%) & $1.06 \pm 0.08 \mathrm{a}$ & $1.00 \pm 0.07 \mathrm{a}$ & $1.03 \pm 0.11 \mathrm{a}$ & 4.29 \\
\hline Viscerosomatic fat $(\%)$ & $4.84 \pm 1.02 \mathrm{a}$ & $4.99 \pm 1.24 \mathrm{a}$ & $5.02 \pm 1.10 \mathrm{a}$ & 11.54 \\
\hline
\end{tabular}

${ }^{(1)}$ Means followed by equal letters, in the rows, do not differ by Tukey's test, at $5 \%$ probability. 


\section{Conclusion}

The replacement of fish oil by soybean oil as a lipid source in diets does not affect the performance or the body composition of fat snook (Centropomus parallelus).

\section{Acknowledgement}

To Secretaria de Ciência e Tecnologia do Estado do Paraná, for financial support.

\section{References}

ALI-SKALLI, J.; ROBIN, J.H. Requirement of n-3 long chain polyunsaturated fatty acids for European sea bass (Dicentrarchus labrax) juveniles: growth and fatty acid composition. Aquaculture, v.240, p.399-415, 2004. DOI: 10.1016/j. aquaculture.2004.06.036.

BORGES, P.; REIS, B.; FERNANDES, T.J.R.; PALMAS, Â.; CASTRO-CUNHA, M.; MÉDALE, F.; OLIVEIRA, M.B.P.P.; VALENTE, L.M.P. Senegalese sole juveniles can cope with diets devoid of supplemental fish oil while preserving flesh nutritional value. Aquaculture, v.418-419, p.116-125, 2014. DOI: 10.1016/j. aquaculture.2013.10.014.

CERQUEIRA, V.R. Cultivo de robalo-peva Centropomus parallelus. In: BALDISSEROTO, B.; GOMES, L.C. (Ed.). Espécies nativas para piscicultura no Brasil. Santa Maria: Ed. da UFSM, 2005. p.403-432.

DING, Z.; XU, Y.; ZHANG, H.; WANG, S.; CHEN, W.; SUN, $Z$. No significant effect of additive ratios of docosahexaenoic acid to eicosapentaenoic acid on the survival and growth of cobia (Rachycentron canadum) juvenile. Aquaculture Nutrition, v.15, p.254-261, 2009. DOI: 10.1111/j.1365-2095.2008.00590.x.

EATON, A.D.; CLESCERI, L.S.; RICE, E.W.; GREENBERG, A.E. Standard methods for the examination of water and wastewater. $21^{\text {th }}$ ed. Washtu Táington: American Public Health Association, 2005. 1325p.

EL-SAYED, A.F.M.; MANSOUR, C.R.; EZZA, T.A.A. Effect of dietary lipid source on spawning performance of Nile tilapia (Oreochromis niloticus) broodstock reared at different water salinities. Aquaculture, v.248, p.187-196, 2005. DOI: 10.1016/j. aquaculture.2005.04.024.

GRIGORAKIS, K. Compositional and organoleptic quality of farmed and wild gilthead sea bream (Sparus aurata) and sea bass (Dicentrarchus labrax) and factors affecting it: a review. Aquaculture, v.272, p.55-75, 2007. DOI: 10.1016/j. aquaculture.2007.04.062.
HORWITZ, W. (Ed.). Official methods of analysis of AOAC Internacional. Maryland: AOAC International, 1997. 1298p.

HUNT, A.O.; TEKELIOGLU, N. Effect of dietary lipid sources on the growth and body fatty acid composition of sea bass (Dicentrarchus labrax L. 1758). Journal of Animal and Veterinary Advances, v.7, p.915-923, 2008.

MOSCHEN, F. Efeito da Artemia enriquecida com ácidos graxos essenciais na larvicultura do robalo-peva (Centropomus parallelus). 2000. 65p. Dissertação (Mestrado) - Universidade Federal de Santa Catarina, Florianópolis.

OSTINI, S.; OLIVEIRA, I. da R.; SERRALHEIRO, P.C. da S.; SANCHES, E.G. Criação do robalo-peva (Centropomus parallelus) submetido a diferentes densidades de estocagem. Revista Brasileira de Saúde e Produção Animal, v.8, p.250-257, 2007.

PENG, S.; CHEN, L.; QIN, J.G.; HOU, J.; NA, Y.; LONG, Z.; YE, J.; SUN, X. Effects of replacement of dietary fish oil by soybean oil on growth performance and liver biochemical composition in juvenile black seabream, Acanthopagrus schlegeli. Aquaculture, v.276, p.154-161, 2008. DOI: 10.1016/j.aquaculture.2008.01.035.

SEIFFERT, M.B.; CERQUEIRA, V.R.; MADUREIRA, L.A. Effect of dietary (n-3) highly unsaturated fatty acids on growth and survival of fat snook (Centropomus parallelus, Pisces: Centropomidae) larvae during first feeding. Brazilian Journal of Medical and Biological Research, v.34, p.645-651, 2001. DOI: 10.1590/S0100-879X2001000500013.

SOUZA, J.H. de; FRACALOSSI, D.M.; GARCIA, A.S.; RIBEIRO, F.F.; TSUZUKI, M.Y. Desempenho zootécnico e econômico de juvenis de robalo-peva alimentados com dietas contendo diferentes concentrações proteicas. Pesquisa Agropecuária Brasileira, v.46, p.190-195, 2011. DOI: 10.1590/S0100-204X2011000200011.

TSUZUKI, M.Y.; BERESTINAS, A.C. Desempenho de juvenis de robalo-peva Centropomus parallelus com diferentes dietas comerciais e freqüências alimentares. Boletim do Instituto de Pesca, v.34, p.535-541, 2008.

TSUZUKI, M.Y.; CARDOSO, R.F.; CERQUEIRA, V.R. Growth of juvenile fat snook Centropomus parallelus in cages at three stocking densities. Boletim do Instituto de Pesca, v.34, p.319-324, 2008.

YANES-ROCA, C.; RHODY, N.; NYSTROM, M.; MAIN, K.L. Effects of fatty acid composition and spawning season patterns on egg quality and larval survival in common snook (Centropomus undecimalis). Aquaculture v.287, p.335-340, 2009. DOI: 10.1016/j.aquaculture.2008.10.043.

ZARZA MEZA, E.A.; VILLALOBOS, J.M.B.; VÁSQUEZ PELÁEZ, C.; ÁLVAREZ TORRES, P. Cultivo experimental de robalo Centropomus undecimalis (Bloch, 1792) y chucumite Centropomusparallelus (Poey, 1860)(Perciformes: Centropomidae) en agua dulce en un estanque de concreto en Alvarado, Veracruz, México. Veterinaria México, v.37, p.327-333, 2006. 